\title{
MANAJEMEN PENDIDIKAN MADRASAH IBTIDAIYAH
}

\author{
Akhmad Sirojudin \\ Institut Pesantren KH. Abdul Chalim \\ e-Mail: akhmadsirojudin86@gmail.com
}

\begin{abstract}
Abstrak
Madrasah mulai didirikan dan berkembang pada abad ke $5 \mathrm{H}$ atau abad ke10 atau ke-11 M. pada masa itu ajaran agama Islam telah berkembang secara luas dalam berbagai macam bidang ilmu pengetahuan, dengan berbagai macam mazhab atau pemikirannya. Pembagian bidang ilmu pengetahuan tersebut bukan saja meliputi ilmu-ilmu yang berhubungan dengan al-Qur'an dan hadis, seperti ilmu-ilmu al-Qur'an, hadits, fiqh, ilmu kalam, maupun ilmu tasawwuf tetapi juga bidang-bidang filsafat, astronomi, kedokteran, matematika dan berbagai bidang ilmu-ilmu alam dan kemasyarakatan. ${ }^{1}$ Aliran-aliran yang timbul akibat dari perkembangan tersebut saling berebutan pengaruh di kalangan umat Islam, dan berusaha mengembangkan aliran dan mazhabnya masing-masing. Maka terbentuklah madrasah-madrasah dalam pengertian kelompok pikiran, mazhab atau aliran. Itulah sebabnya sebahagian besar madrasah didirikan pada masa itu dihubungkan dengan nama-nama mazhab yang masyhur pada masanya, misalnya madrasah Syafi'iyah, Hanafiyah, Malikiyah atau Hanbaliyah.

Berdasarkan keterangan di atas, jelaslah bahwa penggunaan istilah madrasah, sebagai lembaga pendidikan Islam maupun sebagai aliran atau mazhab bukanlah sejak awal perkembangan Islam, tetapi muncul setelah Islam berkembang luas dan telah menerima pengaruh dari luar sehingga terjadilah perkembangan berbagai macam bidang ilmu pengetahuan dengan berbagai macam aliran dan mazhabnya. Pada awal perkembangan Islam, terdapat dua jenis lembaga pendidikan dan pengajaran, yaitu kuttab yang mengajarkan cara menulis dan membaca al-Qur'an, serta dasar-dasar pokok ajaran Islam kepada anak-anak yang merupakan pendidikan tingkat dasar. Sedangkan masjid dijadikan sebagai tingkat pendidikan lanjutan pada masa itu yang hanya diikuti oleh orang-orang dewasa. Dari masjid-masjid ini, lahirlah ulama-ulama besar yang ahli dalam berbagai ilmu pengetahuan Islam, dan dari sini pulalah timbulnya aliran-aliran atau mazhab-mazhab dalam berbagai ilmu pengetahuan, yang waktu itu dikenal dengan istilah "madrasah". Kegiatan para ulama dalam mengembangkan ajaran Islam di tengah-tengah masyarakat Islam maju dengan pesatnya, bahkan dari satu periode ke periode berikutnya semakin meningkat.
\end{abstract}

Kata Kunci: Manajemen Pendidikan, Madrasah Ibtidaiyah

\footnotetext{
${ }^{1}$ Hasbullah, Sejarah Pendidikan Islam di Indonesia (Jakarta: PT. Raja Grafindo Persada, 2001), hal. 161.
} 


\section{PENDAHULUAN}

Membahas tentang madrasah merupakan hal menarik di era kontemporer. Mengingat, madrasah merupakan bagian dari sistem pendidikan nasional yang lebih dekat dan familiar dengan rakyat daripada sistem pendidikan formal lainnya. Dalam analisis para pakar pendidikan, madrasah juga lebih strategis dalam pencapaian PUSEFA (Pendidikan untuk Semua-Education for All), karena madrasah lebih murah dalam hal pembiayaan dan lebih mudah dijangkau oleh rakyat kebanyakan (grass root). Hal ini yang menjadikan madrasah semakin menemukan signifikansinya dalam kompetisi global saat ini, sehingga madrasah dapat dikatakan sebagai lembaga pendidikan Islam formal yang amat berkontribusi dalam pemberantasan buta huruf rakyat (Indonesia). ${ }^{2}$

Pada hakikatnya timbulnya madrasah-madrasah di dunia Islam merupakan usaha pengembangan dan penyempurnaan kegiatan proses belajar mengajar dalam upaya untuk menampung pertumbuhan dan perkembangan ilmu pengetahuan dan jumlah pelajar yang semakin meningkat dan bertambah setiap tahun ajaran. Sementara itu, madrasah boleh dikatakan sebagai fenomena baru dari lembaga pendidikan Islam yang ada di Indonesia, yang kehadirannya sekitar permulaan abad ke-20. Namun dalam penyelenggaraan pendidikan dan pengajarannya masih belum punya keseragaman antara daerah yang satu dengan daerah yang lain, terutama sekali menyangkut kurikulum dan rencana pelajaran. Usaha ke arah penyatuan dan penyeragaman sistem tersebut, baru dirintis sekitar tahun 1950 setelah Indonesia merdeka. Dan pada perkembangannya madrasah terbagi dalam jenjang-jenjang pendidikan; Madrasah Ibtidaiyah, Madrasah Tsanawiyah dan Madrasah Aliyah.

Dalam perspektif historis, Indonesia merupakan sebuah negeri muslim yang unik, letaknya sangat jauh dari pusat lahimya Islam (Mekkah). Meskipun Islam baru masuk ke Indonesia pada abad ke tujuh, dunia internasional mengakui bahwa Indonesia merupakan salah satu negara yang mayoritas penduduknya beragama Islam. Hal ini merupakan salah satu indikator keberhasilan Pendidikan Agama Islam di Indonesia.

Lembaga Pendidikan Agama Islam pertama didirikan di Indonesia adalah dalam bentuk pesantren ${ }^{3}$. Dengan karaktemya yang khas "religius oriented", pesantren telah mampu meletakkan dasar-dasar pendidikan keagamaan yang kuat.

\footnotetext{
${ }^{2}$ Supriyanto, Didik. MODELING: Jurnal Program Studi PGMI 2, no. 1 (March 21, 2015): 1.

${ }^{3}$ Sarijo, M., Sejarah Pondok Pesantren di Indonesia. (Jakarta: Dharma Bakti, 1980), dan Dhofier, Z. Tradisi Pesantren, (Jakarta: LP3E,1982).
} 
Para santri tidak hanya dibekali pemahaman tentang ajaran Islam tetapi juga kemampuan untuk menyebarkan dan mempertahankan Islam.

Masuknya model pendidikan sekolah membawa dampak yang kurang menguntungkan bagi umat Islam saat itu, yang mengarah pada lahirnya dikotomi ilmu agama (Islam) dan ilmu sekuler (ilmu umum dan ilmu sekuler Kristen). Dualisme model pendidikan yang konfrontatif tersebut telah mengilhami munculnya gerakan reformasi dalam pendidikan pada awal abad dua puluh. Gerakan reformasi tersebut bertujuan mengakomodasi sistem pendidikan sekolah ke dalam lingkungan pesantren. ${ }^{4}$ Corak model pendidikan ini dengan cepat menyebar tidak hanya di pelosok pulau Jawa tetapi juga di luar pulau Jawa. Dari situlah embrio madrasah lahir.

\section{PEMBAHASAN}

\section{Konsep Pendidikan Islam Kedudukan Pendidikan dalam Islam}

Secara umum Pendidikan Islam adalah ilmu pendidikan yang berdasarkan Islam. oleh sebab itu, Pendidikan Islam harus bersumber kepada Al-qur'an dan hadis $\mathrm{Nabi}^{5}$. Islam adalah agama yang diperintahkan Allah SWT kepada manusia untuk memeluknya secara utuh dan menyeluruh. Ajaran Islam ini diperuntukan bagi manusia sebagai petunjuk ke jalan yang lurus ketika melaksanakan tugas-tugas hidup serta mencapai tujuan hidup di dunia ini. Dengan demikian ajaran Islam diciptakan oleh Allah SWT sesuai dengan proses penciptaan dan tujuan manusia di muka bumi ini. Namun manusia, dengan segala kekurangannya tidak akan menjalankan tuntutan agama Islam dengan baik tanpa mengetahui, mengerti dan memahami Islam secara menyeluruh dan mendalam. untuk dapat mengetahui dan memahami Islam secara menyeluruh tersebut, maka tidak ada jalan izin kecuali melalui pendidikan. Oleh sebab itu, Islam dan pendidikan mempunyai "hubungan yang sangat erat". Hubungan ini digambarkan bahwa Islam sebagai tujuan dan pendidikan adalah alatnya. ${ }^{6}$

Berdasarkan uraian diatas, dapat digaris bawahi bahwa Islam menempatkan pendidikan sebagai suatu kewajiban umat manusia dalam rangka memenuhi fitrahnya sebagai kahlifah dimuka bumi, lebih-lebih jika dikaitkan dengan kekuatan akal dan pikiran yang dimiliki manusia7. Tanpa pendidikan, kekuatan tersebut akan

\footnotetext{
${ }^{4}$ Thoha, Chabib, dan Muth'i, A. PBM-PAI di Sekolah: Eksistensi dan Proses Belajar Mengajar Pendidikan Agama Islam. Yogyakarta: Pustaka Pelajar bekerja sama dengan Fak. Tarbiyah IAIN Walisongo Sernarang, 1998.

${ }^{5}$ Maksum, Madrasah, Sejarah dan Perkembangannya, (Jakarta: Logos, 1999)), hal. 9.

${ }^{6}$ Hery Noer Aly, Ilmu Pendidikan Islam, (Jakarta: Logos, 1999) hal. 1.

${ }^{7}$ Hamdani Ali, Filsafat Pendidikan, (Yogyakarta: Kota Kembang, 1993), hal. 90.
}

MODELING, Volume 6, Nomor 2, September 2019 | 206 
menjadi boomerang bagi kehidupan manusia itu sendiri. Sesuai dengan fitrahnya, ilmu pengetahuan (pendidikan) diberikan Allah SWT kepada manusia untuk mengurus bumi itu. Disinilah letak esensinya, Allah SWT mewajibkan umat manusia untuk menempuh pendidikan.

\section{Tujuan Pendidikan Islam}

Imam Ghazali berpendapat bahwa tujuan pendidikan Islam adalah kesempurnaan insan di dunia dan akhirat. Manusia akan mencapai keutamaan dengan menggunakan ilmu. Keutamaan itu akan memberinya kebahagiaan di dunia serta mendekatkannya kepada Allah SWT, sehingga ia akan mendapatkan kebahagiaan di akhirat. ${ }^{8}$ Pendapat Imam Ghazali ini sejalan dengan sabda Nabi SAW yang artinya :

"Siapa yang ingin hidup di dunia dengan baik hendaklah ia berilmu, dan siapa yang ingin meraih kebahagiaan di akherat hendaklah ia berilmu, dan siapa yang ingin meraih keduanya (dunia dan akherat) hendaklah ia berilmu". (HR. Ahmad $)^{9}$

\section{Hakikat Pendidikan Madrasah Ibtida'iyah Pengertian Madrasah}

Madrasah adalah ujung tombak terdepan dalam pelaksanaan proses pendidikan Islam. Madrasah sebagai lembaga pendidikan yang tumbuh dan berkembang dari tradisi pendidikan agama dalam masyarakat, memiliki arti penting sehingga keberadaannya terus diperjuangkan.

Madrasah adalah "sekolah umum yang bercirikan Islam"10. Pengertian ini menunjukan dari segi materi kurikulum, madrasah mengajarkan pengetahuan umum yang sama dengan sekolah-sekolah umum sederajat, hanya saja yang membedakan madrasah dengan sekolah umum adalah banyak pengetahuan agama yang diberikan, sebagai ciri khas Islam atau sebagai lembaga pendidikan yang berada di bawah naungan Departemen Agama.

Madrasah sebagai salah satu lembaga pendidikan Islam di Indonesia dituntut untuk dapat berpartisipasi dalam usaha membangun manusia Indonesia yang

\footnotetext{
${ }^{8}$ Hery Noer Aly,....hal.77

${ }^{9}$ H. A Kadir Djaelani, Konsepsi Pendidikan Agama Islam dalam Era Globalisasi, (Jakarta : Putra Harapan, 2001), hal. 15

${ }^{10}$ Departemen Agama, Himpunan Peraturan Perundang-undangan Tentang Sistem Pendidikan Nasional, (Jakarta: Ditjenbinbaga Islam, 1991).
} 
berkualitas dan berguna bagi kehidupan. Jenjang pendidikan madrasah yang terdiri atas Madrasah Ibtida'iyah (MI), Madrasah Tsanawiyah (MTs), dan Madrasah Aliah (MA), yang tidak terlepas dari tiga misi atau tujuan yang harus diemban, yaitu ${ }^{11}$ :

1) Menanamkan keimanan kepada peserta didik.

2) Menumbuhkan semangat dan sikap untuk mengamalkan ajaran-ajaran dalam rangka pembangunan.

3) Memupuk toleransi antara sesama pemeluk agama di Indoesia dengan saling memahami misi luhur masing-masing agama.

Dengan demikian posisi madrasah tidak semata-mata dipahami sebagai lembaga pendidikan yang sederajat dengan sekolah-sekolah lain. akan tetapi ia haus dipahami sebagai lembaga pendidikan yang disamping memiliki kesamaan sederajat tersebut dan memiliki misi yang sangat strategis dalam membentuk peserta didik yang religius, dan berakhlak Islami ${ }^{12}$. Secara hakikat pendidikan madrasah pada umumnya bukan hanya saja mengajarkan ilmu sebagai materi, atau keterampilan sebagai kegiatan, melainkan selalu mengaitkan semuanya dengan praktik (amaliah) yang bermuatan nilai dan moral kususnya pada Madrasah Ibtida'iyah karena disinilah titik awal dari semua kegiatan proses belajar mengajar.

\section{Eksistensi Madrasah}

Madrasah sebagai lembaga pendidikan Islam di Indonesia relatif lebih muda dibanding pesantren. Ia lahir pada abad 20 dengan munculnya Madrasah Manba'ul Ulum Kerajaan Surakarta tahun 1905 dan Sekolah Adabiyah yang didirikan oleh Syekh Abdullah Ahmad di Sumatera Barat tahun 1909 (Malik Fadjar, 1998). Madrasah berdiri atas inisiatif dan realisasi dari pembaharuan sistem pendidikan Islam yang telah ada. Pembaharuan tersebut, menurut Karl Sternbrink (1986), meliputi tiga hal, yaitu:

1. Usaha menyempumakan sistem pendidikan pesantren,

2. Penyesuaian dengan sistem pendidikan Barat, dan

3. Upaya menjembatani antara sistem pendidikan tradisional pesantren dan sistem pendidikan Barat.

Madrasah sebagai lembaga pendidikan Islam kini ditempatkan sebagai pendidikan sekolah dalam sistem pendidikan nasional. Munculnya SKB tiga menteri (Menteri Agama, Menteri Pendidikan dan Kebudayaan, dan Menteri dalam Negeri) menandakan bahwa eksistensi madrasah sudah cukup kuat beriringan dengan sekolah umum. Di samping itu, munculnya SKB tiga menteri tersebut juga dinilai

\footnotetext{
${ }^{11}$ Maksum,....hal. 9.

12 Zulkarnain, Transformas di Nilai-Nilai Pendidikan Islam Manajemen Berorientasi Link and Match (Yogyakarta: Pustaka Pelajar dan STAIN Bengkulu, 2008), hal. 31.
} 
sebagai langkah positif bagi peningkatan mutu madrasah baik dari status, nilai ijazah maupun kurikulumnya (Malik Fadjar, 1998). Di dalam salah satu diktum pertimbangkan SKB tersebut disebutkan perlunya diambil langkah-langkah untuk meningkatkan mutu pendidikan pada madrasah agar lulusan dari madrasah dapat melanjutkan atau pindah ke sekolah-sekolah umum dari sekolah dasar sampai perguruan tinggi.

\section{Problema Madrasah}

Sebagai upaya inovasi dalam Sistem Pendidikan Islam, madrasah tidak lepas dari berbagai problema yang dihadapi. Problema-problema tersebut, menurut Darmu'in (1998), antara lain:

1. Madrasah telah kehilangan akar sejarahnya, artinya keberadaan madrasah bukan merupakan kelanjutan pesantren, meskipun diakui bahwa pesantren merupakan bentuk lembaga pendidikan Islam pertama di Indonesia.

2. Terdapat dualisme pemaknaan terhadap madrasah. Di satu sisi, madrasah diidentikkan dengan sekolah karena memiliki muatan secara kurikulum yang relatif sama dengan sekolah umum. Di sisi lain, madrasah dianggap sebagai pesantren dengan sistem klasikal yang kemudian dikenal dengan madrasah diniyah.

Dengan demikian, sebagai sub sistem pendidikan nasional, madrasah belum memiliki jati diri yang dapat dibedakan dari lembaga pendidikan lainnya. Efek pensejajaran madrasah dengan sekolah umum yang berakibat berkurangnya proporsi pendidikan agama dari $60 \%$ agama dan $40 \%$ umum menjadi $30 \%$ agama dan $70 \%$ umum dirasa sebagai tantangan yang melemahkan eksistensi pendidikan Islam. Beberapa permasalahan yang muncul kemudian, antara lain:

1. Berkurangnya muatan materi pendidikan agama. Hal ini dilihat sebagai upaya pendangkalan pemahaman agama, karena muatan kurikulum agama sebelum SKB dirasa belum mampu mencetak muslim sejati, apalagi kemudian dikurangi.

2. Tamatan Madrasah serba tanggung. Pengetahuan agamanya tidak mendalam sedangkan pengetahuan umumnya juga rendah.

Diakui bahwa model pendidikan madrasah di dalam perundang-undangan negara, memunculkan dualisme sistem Pendidikan di Indonesia. Dualisme pendidikan di Indonesia telah menjadi dilema yang belum dapat diselesaikan hingga sekarang. Dualisme ini tidak hanya berkenaan dengan sistem pengajarannya tetapi juga menjurus pada keilmuannya. Pola pikir yang sempit cenderung membuka gap antara ilmu-ilmu agama Islam dan ilmu-ilmu umum. Seakan-akan muncul ilmu Islam 
dan ilmu bukan Islam (kafir). Padahal dikhotomi keilmuan ini justru menjadi garapan bagi para pakar pendidikan Islam untuk berusaha menyatukan keduanya.

Dualisme pendidikan Islam juga muncul dalam bidang manajerialnya, khususnya di lembaga swasta. Lembaga swasta umumnya memiliki dua top manager yaitu kepala madrasah dan ketua yayasan (atau pengurus). Meskipun telah ada garis kewenangan yang memisahkan kedua top manager tersebut, yakni kepala madrasah memegang kendali akademik sedangkan ketua yayasan (pengurus) membidangi penyediaan sarana dan prasarana, sering di dalam praktik terjadi overlapping. Masalah ini biasanya lebih buruk jika di antara pengurus yayasan tersebut ada yang menjadi staf pengajar. Di samping ada kesan mematai-matai kepemimpinan kepala madrasah, juga ketika staf pengajar tersebut melakukan tindakan indisipliner (sering datang terlambat), kepala madrasah merasa tidak berdaya menegumya.

Praktek manajemen di madrasah sering menunjukkan model manajemen tradisional, yakni model manajemen paternalistik atau feodalistik. Dominasi senioritas semacam ini terkadang mengganggu perkembangan dan peningkatan kualitas pendidikan. Munculnya kreativitas inovatif dari kalangan muda terkadang dipahami sebagai sikap yang tidak menghargai senior. Kondisi yang demikian ini mengarah pada ujung ekstrem negatif, hingga muncul kesan bahwa meluruskan langkah atau mengoreksi kekeliruan langkah senior dianggap tabiat su'ul adab.

Dualisme pengelolaan pendidikan juga terjadi pada pembinaan yang dilakukan oleh departemen yaitu Departemen Pendidikan Nasional (Depdiknas) dan Departemen Agama (Depag). Pembinaan Madrasah di bawah naungan Depag berhadapan dengan Sekolah umum di bawah pembinaan Depdiknas sering menimbulkan kecemburuan sejak di tingkat (SD dan MI) hingga perguruan tinggi. Dari alokasi dana, perhatian, pembinaan manajerial, bantuan buku dan media pembelajaran, serta penempatan guru, hingga pemberian beasiswa pendidikan lanjut sering tidak sama antara yang diterima oleh sekolah umum (Depdiknas) dengan madrasah (Depag).

Kesenjangan antara madrasah swasta dan madrasah negeri pun tampaknya juga menjadi masalah yang belum tuntas diselesaikan. Gap tersebut meliputi beberapa hal seperti pandangan guru, sarana dan prasarana, kualitas input siswa dan sebagainya yang kesemuanya itu berpengaruh baik langsung maupun tidak langsung kepada mutu pendidikan. Yang demikian ini karena munculnya SKB tiga menteri tersebut belum diimbangi penyediaan guru, buku-buku dan peralatan lain dari departemen terkait ${ }^{13}$.

\section{Hakikat Pendidikan Islam di Madrasah Ibtida'iyah}

${ }^{13}$ Fadjar, M.A.. Madrasah dan Tantangan Modernitas, (Bandung: Mizan, 1998). 
Hakikat pendidikan madrasah seiring dengan tujuan pendidikan melalui misi madrasah. Dalam rangka perwujudan hakikat tersebut sudah barang tentu memerlukan suatu perangkaat operasional yang berkualitas yang selalu dikembangkan sesuai dengan kemajuan dan kebutuhan masyarakat, melalui peningkatan berbagai komponen seperti pengembangan kurikulum dan metodelogi, pemenuhan dan peningkatan mutu kemampuan tenaga pendidik, sarana dan prasarana dan lain-lain.

Madrasah sebagai lembaga Pendidikan Islam harus senantiasa bertitik tolak dari rumusan dia atas sehingga out put dari lembaga ini mampu bersaing dengan lembaga pendidikan lain. Ada beberapa unsur pendidikan yang harus dipenuhi agar tujuan Madrasah bisa tercapai :

1) Bahwa pendidikan itu harus merupakan usaha sadar yang dilakukan oleh orang tua atau orang dewasa atau siapa saja yang bertanggung jawab dalam rangka membimbing dan mempersiapkan anak, dengan atas nama Allah SWT serta bertasnggung jawan kepada-Nya.

2) Bahwa yang dibimbing dengan pendidikan itu adalah anak atau generasi dengan seluruh kelengkapan dasar potensi-potensi pembawaan fitrahnya, agar tumbuh berkembang secara bertahap dan berangsur-angsur kearah sempurna.

3) Tujuan pembimbingan dan pendidikan adalah agar anak nantinya mampu melakasanakan tugas-tugas hidup yaitu tugas kekhalifahan dengan penuh tanggung jawab kepada Allah SWT.

4) Karena pedomannya adalah Al-qur'an, baik secara konseptual maupun praktis, maka metode, cara pelaksanaannya, materi, dan kurikulum, evaluasi dan alat pendidikan lainnya, dapat dijabarkan dan dikembangkan dari Al-qur'an, mulai dari proses turunnya, penjelasan-penjelasan dari Nabi serta contoh-contoh yang telah diberikan oleh Nabi Muhammad SAW ${ }^{14}$.

\section{Kedudukan Madrasah dalam Sistem Pendidikan Nasional}

Dengan dikeluarkannya Kepres No. 34 tahun 1972 dan Inpres No. 15 tahun 1974, pemerintah mengambil kebijakan yang lebih operasional terhadap madrasah. dikeluarkannya SKBL (Surat Keputusan Bersama) Tiga Menteri, yaitu, Menteri Agama, Pendidikan dan kebudayaan, dan Menteri Dalam Negeri. Dapat dipandang sebagai pengakuan yang lebih nyata terhadap kedudukan Madrasah dalam Sistem Pendidikan Nasional di Indoensia. Dalam konteks ini, sejumlah diktum yang memperkuat posisi Madrasah diantaranya adalah :

Bab I ayat 2 : Madrasah meliputi tiga tingkatan :

\footnotetext{
${ }^{14}$ Tadjab, Perbandingan Pendidikan, (Surabaya : Karya Abditama, 2000), hal. 58.
} 
1) Madrasah Ibtida'iyah, setingkat dengan Sekolah dasar.

2) Madrsah Tsanawiyah setingkat dengan Sekolah Menengah Pertama.

3) Madrasah Aliyah setingkat dengan Sekolah Menengah Atas.

\section{Bab II pasal 2}

1) Ijazah madrasah dapat mempunyai nilai yang sama dengan ijazah sekolah umum yang setingkat.

2) Luluran madrasah dapat melanjutkan ke sekolah umum setingkat atas.

3) Siswa madrasah sapat berpindah ke sekolah umum yang setingkat,

Kedudukan Madrasah dalam pendidikan nasional lebih dipertegas lagi dalam Keputusan Menteri Agama RI No. 372 tahun 1993 tentang Kurikulum Pendidikan Dasar bercirikan khas Agama Islam. Dalam keputusan ini dinyatakan bahwa Madrasah Ibtida'iyah dan Madrasah Tsanawiyah melaksanakan Kurikulum Nasional Sekolah Dasar dan Sekolah Lanjutan Tingkat Pertama.

Posisi integrasi pendidikan Islam dalam sistem Penddikan Nasional selain pada beberapa poin diatas juga tercermin dalam beberapa aspek sebagai berikut :

1) Pendidikan nasional menjadi pendidikan agama sebagai salah satu muatan wajib dalam jalur dan jenis pendidikan.

2) Madrasah dalam sistem pendidikan nasional, dengan sendirinya dimasukan dalam kategori pendidikan jalur sekolah.

3) Meskipun Madrasah diberi status pendidikan jalur sekolah tetapi sesuai dengan jenis keagamaan dalam sistem pendidikan nasional, Madrasah memiliki jalur khusus ilmu-ilmu syari'ah ${ }^{15}$.

Mengingat posisi dan kedudukan madrasah diatas tentunya merupakan suatu tanggung jawab bagi setiap komponen yang terlibat didalamnya untuk mempertahankan posisi tersebut dan menjadikannya sebagai salah satu keunggulan madrasah dalam dunia pendidikan nasional.

\section{Pendidikan Islam Alternatif Upaya Mengembangkan Madrasah}

Dalam upaya mencari "model alternatif pendidikan Islam" yang akan disesuaikan dengan kebutuhan masyarakat madani Indonesia, paling tidak ada tiga pendekatan yang ditawarkan sebagai pola alternatif pendidikan Islam, yaitu

1) Pendekatan sistemik, yaitu perubahan harus dilakukan terhadap keseluruhan sistem pada lembaga pendidikan Islam formal yang ada, dalam arti terjadi perubahan total.

2) Pendekatan suplementer, yaitu dengan menambah sejumlah paket pendidikan yang bertujuan memperluas pemahaman dan penghayatan ajaran Islam secara lebih memadai. Langkah ini yang sering dilakukan dengan istilah yang populer adalah "tambal sulam".

\footnotetext{
15 Maksum,...hal. 159.
} 
3) Pendekatan komplementer, yaitu dengan upaya mengubah kurikulum dengan sedikit radikal untuk disesuaikan secara terpadu ${ }^{16}$. Artinya, untuk kondisi sekarang ini, perubahan kurikulum pendidikan Islam harus diorientasikan pada kompetensi yaitu kompetensi knowledge (pengetahuan), skill (keterampilan atau kemahiran), kompetensi ability (memiliki kemampuan tertentu), komptensi sosial-kultural, dan kompetensi spritual ilahiyah ${ }^{17}$.

Dari uraian diatas, menegaskan bahwa lembaga-lembaga pendidikan Islam khususnya lembaga pendidikan Islam seperti madrasah (MI, MTs, dan MA) harus mendisain model-model pendidikan alternatif yang sesuai dengan kebutuhan perkembangan sekarang ini. Dari sini muncul pertanyaan penting tentang modelmodel pendidikan Islam yang diharapkan dapat menghadapi dan menjawab tantangan perubahan yang terjadi dalam kehidupan masyarakat baik sosial maupun kultural menuju masyarakat Indonesia baru.

Untuk menjawab pertanyaan ini, meminjam prinsip hakekat pendidikan Islam yang digunakan Hasim Amir, yang mengemukakan bahwa pendidikan Islam adalah pendidikan yang idealistik, yakni pendidikan yang integralistik, humanistik, pragmatik dan berakar pada budaya kuat. Tawaran Hasim Amir ini, yang dikutip A. Malik Fadjar, dapat digunakan sebagai konsep pendidikan Islam dalam menghadapi perubahan masyarakat Indonesia, yaitu:

Pertama, pendidikan integralistik, merupakan model pendidikan yang diorientasikan pada komponen-komponen kehidupan yang meliputi: Pendidikan yang berorientasi pada Rabbaniyah (Ketuhanan), insaniyah (kemanusiaan) dan alamiyah (alam pada umumnya), sebagai suatu yang integralistik bagi perwujudan kehidupan yang baik dan untuk mewujudkan rahmatan lil 'alamin, serta pendidikan yang menggap manusia sebagai sebuah pribadi jasmani-rohani, intelektual, perasaan dan individual-sosial. Pendidikan integralistik diharapkan dapat menghasilkan manusia (peserta didik) yang memiliki integritas tinggi, yang dapat bersyukur dan menyatu dengan kehendak Tuhannya, menyatu dengan dirinya sendiri sehingga tidak memiliki kepribadian belah atau kepribadian mendua, menyatu dengan masyarakat sehingga dapat menghilangkan disintegrasi sosial, dan dapat menyatu dengan alam sehingga tidak membuat kerusakan, tetapi menjaga, memelihara dan memberdayakan serta mengoptimalkan potensi alam sesuai kebutuhan manusia.

\footnotetext{
${ }^{16}$ Suroyo, Perbagai Persoalan Pendidikan; Pendidikan Nasional dan Pendidikan Islam di Indonesia, Jurnal Pendidikan Islam, Kajian tentang Konsepo Pendidikan Islam, Problem dan Prospeknya, Volume 1 Tahun 1991, (Yogyakarta: Fakultas Tarbiyah IAIN, 1991). hal. 64.
}

${ }^{17}$ A. Malik. Fadjar, 1999, Reformasi Pendidikan Islam, Jakarta: Fajar Dunia. hal. 37

213 | MODELING, Volume 6, Nomor 2, September 2019 
Kedua, pendidikan yang humanistik, merupakan model pendidikan yang berorientasi dan memandang manusia sebagai manusia (humanisasi), yakni makhluk ciptaan Tuhan dengan fitrahnya. Maka manusia sebagai makhluk hidup, ia harus mampu melangsungkan, mempertahankan, dan mengembangkan hidupnya. Maka posisi pendidikan dapat membangun proses humanisasi, artinya menghargai hak-hak asasi manusia, seperti hak untuk berlaku dan diperlakukan dengan adil, hak untuk menyuarakan kebenaran, hak untuk berbuat kasih sayang, dan lain sebagainya. Maka, manusia "yang manusiawi" yang dihasilkan oleh pendidikan yang humanistik diharapkan dapat mengembangkan dan membentuk manusia berpikir, berasa dan berkemauan dan bertindak sesuai dengan nilai-nilai luhur kemanusiaan yang dapat mengganti sifat individualistik, egoistik, egosentrik dengan sifat kasih sayang kepada sesama manusia, sifat menghormati dan dihormati, sifat ingin memberi dan menerima, sifat saling menolong, sifat ingin mencari kesamaan, sifat menghargai hakhak asasi manusia, sifat menghargai perbedaan dan sebagainya.

Ketiga, pendidikan pragmatik adalah pendidikan yang memandang manusia sebagai makhluk hidup yang selalu membutuhkan sesuatu untuk melangsungkan, mempertahankan dan mengembangkan hidupnya baik bersifat jasmani maupun rohani, seperti berpikir, merasa, aktualisasi diri, keadilan, dan kebutuhan spritual ilahiyah. Dengan demikian, model pendidikan dengan pendekatan pragmatik diharapkan dapat mencetak manusia pragmatik yang sadar akan kebutuhankebutuhan hidupnya, peka terhadap masalah-masalah sosial kemanusiaan dan dapat membedakan manusia dari kondisi dan situasi yang tidak manusiawi.

Keempat, pendidikan yang berakar pada budaya, yaitu pendidikan yang tidak meninggalkan akar-akar sejarah, baik sejarah kemanusiaan pada umumnya maupun sejarah kebudayaan suatu bangsa, kelompok etnis, atau suatu masyarakat tertentu. Maka dengan model pendidikan yang berakar pada budaya, diharapkan dapat membentuk manusia yang mempunyai kepribadian, harga diri, percaya pada diri sendiri, dan membangun peradaban berdasarkan budaya sendiri yang akan menjadi warisan monumental dari nenek moyangnya dan bukan budaya bangsa lain. ${ }^{18}$ Tetapi dalam hal ini bukan berarti kita menjadi orang yang anti kemodernan, perubahan, reformasi dan menolak begitu saja arus transformasi budaya dari luar tanpa melakukan seleksi dan alasan yang kuat.

Selanjutnya, dari keempat model yang dikemukakan di atas, dapat ditarik lagi pada disain model pendidikan Islam yang lebih operasional, yaitu:

Pertama, mendisain model pendidikan umum Islami yang handal dan mampu bersaing dengan lembaga-lembaga pendidikan yang lain. Dengan demikian, visi, misi dan tujuan pendidikan, kurikulum dan materi pembelajaran, metode pembelajaran, manajemen pendidikan, organisasi dan sumber daya pendidikan (guru dan tenaga

${ }^{18}$ A. Malik. Fajar....hal. 37-39.

MODELING, Volume 6, Nomor 2, September 2019 | 214 
administrasi) harus disesuaikan dengan kebutuhan serta sesuai misi, visi dan tujuan pendidikan tersebut. Model pendidikan umum Islami, kurikulumnya bersifat integratif antara materi-materi pendidikan umum dan agama, sehingga mampu mempersiapkan intelektual Islam yang berfikir secara komprehensif. Atau meminjam istilah Fazlur Rahman, yaitu model pendidikan sekuler modern dan mengisinya dengan konsepkonsep Islam, untuk melahirkan intelektualisme muslim yang tangguh, walaupun Ahmad Syafii Maarif, menolak hal ini yaitu kita tidak perlu berteriak untuk mengislamkan ilmu modern.

Kedua, model pendidikan Islam yang tetap mengkhususkan pada disain "pendidikan keagamaan" seperti sekarang ini. Artinya, harus mendisain ulang model "pendidikan Islam" yang berkualitas dan bermutu yaitu, pertama dengan merumuskan visi dan misi serta tujuan yang jelas, kedua, kurikulum dan materi pembelajaran diorientasikan pada kebutuhan peserta didik dan kebutuhan masyarakat untuk dapat menjawab tantangan perubahan, ketiga, metode pembelajaran diorientasikan pada upaya pemecahan kasus (promlem solving) dan bukan dominasi ceramah, keempat, manajemen pendidikan diorientasi pada manajemen berbasis sekolah, kelima, organisasi dan sumber daya guru yang memiliki kompetensi dan profesional dalam bidangnya masing-masing. Maka pendidikan Islam akan mampu bersaing dengan mampu mempersiapkan dan melahirkan mujtahidmujtahid yang tangguh, berkualitas dan berkaliber dunia dalam bidangnya sehingga mampu menjawab persoalan-persoalan aktual atau kontemporer sesuai dengan kebutuhan perubahan zaman. Disain model pendidikan seperti ini, harus secara "selektif menerima" pendidikan produk barat, berarti harus mendisain model pendidikan yang betul-betul sesuai dengan konsep dasar Islam dan sesuai dengan lingkungan sosial-budaya Indonesia. Kata Fazlur Rahman, apabila kita ingin membangun pendidikan Islam yang berkualitas, harus kembali kepada al-Qur'an dan Qur'an harus ditempatkan sebagai pusat intelektualisme Islam ${ }^{19}$.

Ketiga, model pendidikan agama Islam tidak dilaksanakan di sekolah-sekolah formal tetapi dilaksanakan di luar sekolah. Artinya pendidikan agama dilaksanakan di rumah atau lingkungan keluarga, masjid dan lingkungan masyarakat (tempat-tempat pengajian dan Masjid) dalam bentuk kursur-kursus, kajian-kajian keagamaan, keterampilan beribadah dan sebagainya. Pendidikan agama akan menjadi tanggungjawab orang tua dan masyarakat atau meminjam konsep Yahya Muhaimin ${ }^{20}$

\footnotetext{
19 Fazlur Rahman, Islam dan Modernitas tentang Transformasi Intelektual, Terj. Ahsin Mohammad, (Bandung: Pustaka, 1985) hal. 1.

${ }^{20}$ Yahya Muhaimin, (Menteri Pendidikan Nasional), 2000, "Reformasi Pendidikan Nasional Munuju Indonesia", Majalah Dwiwutan BPK Penabur Jakarta, Midyawarta, No. 69/Thn.XII, From: www.bpk. Penabur. Ci.id,diakses hari kamis, tanggal 4 maret 2010.
} 
yang dikemukakan terdahulu bahwa pendidikan berbasis keluarga (family-based education) dan pendidikan berbasis pada masyarakat (community-based education). Pendidikan Islam, dapat ditanamkan dan disosialisasikan secara intensif melalui basis-basis tersebut, sehingga Pendidikan Agama sudah menjadi kebutuhan dan based dalam pribadi peserta didik. Maka dalam proses belajar mengajar di sekolah pendidikan agama telah menjadi kebutuhan dan prilaku (afektif dan psikomotorik) yang aktual, bukan lagi berupa pengetahuan (knowledge) yang dihafal (kognitif) dan diujikan secara kognitif pula.

Keempat, disain model pendidikan diarahkan pada dua dimensi yakni, pertama dimensi dialektika [horisontal], pendidikan hendaknya dapat mengembangkan pemahaman tentang kehidupan manusia dalam hubungannya dengan alam atau lingkungan sosialnya. Manusia harus mampu mengatasi tantangan dan kendala dunia sekitarnya melalui pengembangan Iptek, dan kedua dimensi ketunduhan vertikal, pendidikan selain menjadi alat untuk memantapkan, memelihara sumber daya alami, juga menjembatani dalam memahamai fenomena dan misteri kehidupan yang abadi dengan Maha Pencipta ${ }^{21}$. Berarti pendidikan harus disertai dengan pendekatan hati, artinya pendidikan harus membangun hubungan manusia dengan Tuhannya, sesama manusia, dan lingkungan.

Keempat model pendidikan Islam yang dikemukakan diatas merupakan tawaran desain dan model pendidikan Islam yang perlu diupayakan untuk membangun paradigma pendidikan Islam dalam menghadapi perkembangan perubahan zaman modern dan memasuki masyarakat madani Indonesia. Kecenderungan perkembangan semacam, dalam upaya mengantisipasi perubahan zaman dan merupakan hal yang wajar-wajar saja. Sebab kondisi masyarakat sekarang ini lebih bersifat praktis-pragmatis dalam hal aspirasi dan harapan terhadap pendidikan, sehingga pendidikan tidak statis atau hanya berjalan di tempat dalam menatap persoalan-persoalan yang dihadapi pada era masyarakat modern, post masyarakat modern dan masyarakat global.

Dengan demikian, apapun model pendidikan Islam yang ditawarkan dalam masyarakat Indonesia, pada dasarnya harus berfungsi untuk memberikan kaitan antara peserta didik dengan nilai-nilai ilahiyah, pengetahuan dan keterampilan, nilainilai demokrasi, masyarakat dan lingkungan sosio-kulturalnya yang terus berubah dengan cepat, sebab pada saat yang sama pendidikan secara sadar juga digunakan sebagai instrumen untuk perubahan dalam sistem politik, ekonomi secara keseluruhan.

\footnotetext{
${ }^{21}$ M. Irsyad Sudiro, Pendidikan Agama dalam Masyarakat Modern, (Cirebon: Seminar dan Lokakarya Nasional Revitalisasi Pendidikan Luar Sekolah dalam Masyarakat Modern, Cirebon, Tanggal, 30 Agustus - 1 September 1995). hal. 2
} 


\section{KESIMPULAN}

Pada hakikatnya timbulnya madrasah-madrasah di dunia Islam merupakan usaha pengembangan dan penyempurnaan kegiatan proses belajar mengajar dalam upaya untuk menampung pertumbuhan dan perkembangan ilmu pengetahuan. Dalam perspektif historis, Indonesia merupakan sebuah negeri muslim yang unik, letaknya sangat jauh dari pusat lahimya Islam (Mekkah). Meskipun Islam baru masuk ke Indonesia pada abad ke tujuh, dunia internasional mengakui bahwa Indonesia merupakan salah satu negara yang mayoritas penduduknya beragama Islam. Hal ini merupakan salah satu indikator keberhasilan Pendidikan Agama Islam di Indonesia.

Lembaga Pendidikan Agama Islam pertama didirikan di Indonesia adalah dalam bentuk pesantren. Dengan karaktemya yang khas "religius oriented", pesantren telah mampu meletakkan dasar-dasar pendidikan keagamaan yang kuat. Para santri tidak hanya dibekali pemahaman tentang ajaran Islam tetapi juga kemampuan untuk menyebarkan dan mempertahankan Islam.

Madrasah Ibtida'iyah adalah awal dari ujung tombak terdepan dalam pelaksanaan proses pendidikan Islam. Madrasah Ibtida'iyah sebagai lembaga pendidikan awal yang tumbuh dan berkembang dari tradisi pendidikan agama dalam masyarakat, memiliki arti penting sehingga keberadaannya terus diperjuangkan dan siswa yang ingin melajutkan kejenjang selanjutnya tidak diragukan lagi dalam pengalaman pendidikan yang ia tempuh selama di Madrasah Ibtida'iyah .

Hakikat pendidikan madrasah seiring dengan tujuan pendidikan melalui misi madrasah khususnya pada Madrasah Ibtida'iyah. Dalam rangka perwujudan hakikat tersebut sudah barang tentu memerlukan suatu perangkaat operasional yang berkualitas yang selalu dikembangkan sesuai dengan kemajuan dan kebutuhan masyarakat, melalui peningkatan berbagai komponen seperti pengembangan kurikulum dan metodelogi, pemenuhan dan peningkatan mutu kemampuan tenaga pendidik, sarana dan prasarana dan lain-lain. Madrasah sebagai lembaga Pendidikan Islam harus senantiasa bertitik tolak dari rumusan dia atas sehingga out put dari lembaga ini mampu bersaing dengan lembaga pendidikan lain.

Dengan dikeluarkannya Kepres No. 34 tahun 1972 dan Inpres No. 15 tahun 1974, pemerintah mengambil kebijakan yang lebih operasional terhadap madrasah. dikeluarkannya SKBL (Surat Keputusan Bersama) Tiga Menteri, yaitu, Menteri Agama, Pendidikan dan kebudayaan, dan Menteri Dalam Negeri. Dapat dipandang sebagai pengakuan yang lebih nyata terhadap kedudukan Madrasah dalam Sistem Pendidikan Nasional di Indoensia. 


\section{DAFTAR PUSTAKA}

Aly, Hery Noer. 1999. Ilmu Pendidikan Islam, Jakarta: Logos.

Ali, Hamdani. 1993. Filsafat Pendidikan, Yogyakarta: Kota Kembang.

Djaelani, H. A Kadir. 2001. Konsepsi Pendidikan Agama Islam dalam Era Globalisasi, Jakarta: Putra Harapan.

Departemen Agama. 1991. Himpunan Peraturan Perundang-undangan Tentang Sistem Pendidikan Nasional, Jakarta : Ditjenbinbaga Islam.

Dhofier, Z. 1982. Tradisi Pesantren, Jakarta: LP3E.

Fadjar, A. Malik. 1999. Reformasi Pendidikan Islam, Jakarta: Fajar Dunia.

Fadjar, M.A. 1998. Madrasah dan Tantangan Modernitas. Bandung: Mizan.

Hasbullah. 2001. Sejarah Pendidikan Islam di Indonesia, Jakarta: PT. Raja Grafindo Persada.

Maksum. 1999. Madrasah, Sejarah dan Perkembangannya, Jakarta: Logos.

Muhaimin, Yahya (Menteri Pendidikan Nasional). 2000. "Reformasi Pendidikan Nasional Munuju Indonesia”, Majalah Dwiwutan BPK Penabur Jakarta, Midyawarta, No. 69/Thn.XII, From: www.bpk. Penabur.co.id.

Rahman, Fazlur. 1985. Islam dan Modernitas tentang Transformasi Intelektual, Terj. Ahsin Mohammad, Bandung: Pustaka.

Sarijo, M. (1980). Sejarah Pondok Pesantren di Indonesia. Jakarta: Dharma Bakti.

Supriyanto, Didik. MODELING: Jurnal Program Studi PGMI 2, No. 1 (March 21, 2015): 70-84.

Suroyo, 1991, Perbagai Persoalan Pendidikan; Pendidikan Nasional dan Pendidikan Islam di Indonesia, Jurnal Pendidikan Islam, Kajian tentang Konsepo Pendidikan Islam, Problem dan Prospeknya, Volume 1 Tahun 1991, (Yogyakarta : Fakultas Tarbiyah IAIN.

Sudiro, M. Irsyad., Pendidikan Agama dalam Masyarakat Modern, Seminar dan Lokakarya Nasional Revitalisasi Pendidikan Luar Sekolah dalam Masyarakat Modern, Cirebon, Tanggal, 30 Agustus - 1 September 1995. 
Thoha, Chabib, dan Muth'i, A. (1998). PBM-PAI di Sekolah: Eksistensi dan Proses Belajar Mengajar Pendidikan Agama Islam. Yogyakarta: Pustaka Pelajar bekerja sama dengan Fak. Tarbiyah IAIN Walisongo Sernarang

Tadjab, 2000, Perbandingan Pendidikan, Surabaya: Karya Abditama.

Zulkarnain, 2008, Transformasdi Nilai-Nilai Pendidikan Islam Manajemen Berorientasi Link and Match Yogyakarta: Pustaka Pelajar dan STAIN Bengkulu.

219 | MODELING, Volume 6, Nomor 2, September 2019 